\title{
Two new Entyloma species (Entylomatales, Ustilaginomycotina) from the USA
}

\section{Teodor T. Denchev ${ }^{1}$, Cvetomir M. Denchev ${ }^{1 *} \&$ Roger G. Shivas ${ }^{2}$}

${ }^{1}$ Institute of Biodiversity and Ecosystem Research, Bulgarian Academy of Sciences, 2 Gagarin St., 1113 Sofia, Bulgaria

${ }^{2}$ Plant Pathology Herbarium, Department of Agriculture, Fisheries and Forestry, Ecosciences Precinct, GPO Box 267, Brisbane, Qld 4001, Australia

Received 13 December 2013 / Accepted 16 December 2013 / Published 17 December 2013

Denchev, T.T., Denchev, C.M. \& Shivas, R.G. 2013. Two new Entyloma species (Entylomatales, Ustilaginomycotina) from the USA. - Mycobiota 3: 35-39. doi: 10.12664/mycobiota.2013.03.04

Abstract. Two new Entyloma species, E. castillejae on Castilleja (Orobanchaceae) and E. violae on Viola (Violaceae), are described and illustrated from the USA.

Key words: Castilleja, Entyloma, Orobanchaceae, smut fungi, taxonomy, USA, Viola

\section{Introduction}

Revision of Entyloma specimens from the herbarium of the Swedish Museum of Natural History, Stockholm (S) yielded two new species on host genera from which Entyloma had not been previously recorded.

The species of Entyloma form sori in vegetative organs (mostly in leaves, rarely in stems, occasionally in roots) of dicotyledonous plants, usually forming few to numerous spots, sometimes swellings or galls formed by hypertrophic growth of host tissue. The spores are permanently embedded in the host tissue, single or in irregular groups, hyaline, yellow or yellowish brown, usually with a smooth, two-layered wall, often with a hyaline gelatinous sheath; very rarely the outer layer is tuberculate (e.g., E. verruculosum) or with prismatic, pyramidal or coarse, irregular thickenings (e.g., E. urocystoides).

Entyloma comprises about 180 species on host plants belonging to 25 families (Vánky 2013). There are 47 species known from the USA: E. achilleae Magnus, E. agoseridis Zundel, E. anceps Cif., E. arnicale Ellis \& Everh., E. asteris-sericei Zundel, E. australe Speg., (?) E. bidentis Henn., E. boltoniae Cif., E. calendulae (Oudem.) de Bary, E. clintonianum

*Corresponding author: e-mail: cmdenchev@yahoo.co.uk 
Zundel \& Dunlap, E. collinsiae Harkn., E. compositarum Farl., E. dahlia Syd. \& P. Syd., E. davisii Cif., E. echinaceae Vánky \& McKenzie, E. ellisii Halst., E. erigerontis Syd. \& P. Syd. ex Cif., E. eschscholziae Harkn., E. eupatorii Cif., (?) E. ficariae A.A. Fisch. Waldh., E. fimbriatum G.W. Fisch., E. floerkeae Holw., E. fuscum J. Schröt., E. gaillardianum Vánky, E. gratiolae (Davis) Cif., E. guaraniticum Speg., E. heterothecae Vánky, E. hieracii Syd. \& P. Syd., E. holwayi P. Syd., E. lapponicum Liro, E. lepachydis Cif., E. linariae J. Schröt., E. lithophragmatis G.W. Fisch. \& C.G. Shaw, E. lobeliae Farl., E. madiae Cif., E. martindalei (Peck) Piątek, E. meliloti McAlpine, E. menispermi Farl. \& Trel., E. microsporum (Unger) J. Schröt., E. polysporum (Peck) Farl., E. saccardianum Scalia ex Cif., E. saniculae Peck, E. serotinum J. Schröt., E. thalictri J. Schröt., E. trigonellae J.A. Stev., E. veronicae (Halst.) Lagerh., and E. winteri Linh. (Vánky 2011; Farr \& Rossman 2013). However the available specimens of Entyloma from the USA need revision because the scientific literature indicates that there are many fungus-host combinations that do not correspond to the modern taxonomic concept of this genus (Vánky 2013).

\section{Material and methods}

Dried specimens from the mycological collection of $S$ were examined under light (LM) and scanning electron (SEM) microscopes. For LM observations, spores were mounted in lactophenol solution on glass slides, gently heated to boiling point to rehydrate the spores, and then cooled. Spore measurements are given in the form: min-max (extreme values) [mean \pm 1 standard deviation]. For SEM, spores were attached to specimen holders by double-sided adhesive tape and coated with gold with an ion sputter. The surface structure of spores was observed at $10 \mathrm{kV}$ and photographed with a JEOL JSM-5510 scanning electron microscope.

\section{Taxonomy}

Entyloma castillejae T. Denchev, Denchev \& R.G. Shivas, sp. nov.

Figs 1-4

IF 550279

Differs from all other Entyloma species by specialisation on Castilleja.

Type in leaves of Castilleja sp.: USA, Colorado, Gothic Biol. Station, 14 July 1931, B. Palm (holotype, S F157 103).

Etymology: the name refers to the host species.

Sori in leaves, forming irregularly rounded spots, single to few in an infected leaf, amphigenous, $0.5-3 \mathrm{~mm}$ in length, usually between the veins, brownish. Spores embedded in leaf tissue, crowded, globose, subglobose, broadly ellipsoidal or slightly irregular, (8.5-)9.5$14.5(-16.0) \times(8.0-) 9.0-13.5[12.1 \pm 1.2 \times 11.1 \pm 1.2] \mu \mathrm{m}(\mathrm{n}=100)$, subhyaline to light yellow-brown; wall two-layered, inner layer evenly thickened, 0.6-0.8 $\mu \mathrm{m}$ thick, light yellow-brown, outer layer slightly uneven, $1.0-1.7(-2.0) \mu \mathrm{m}$ thick, subhyaline, smooth, in old spores sometimes ruptured; in SEM the spore surface rough. Anamorph present.

Distribution: on Castilleja (Orobanchaceae), known only from the type locality. 

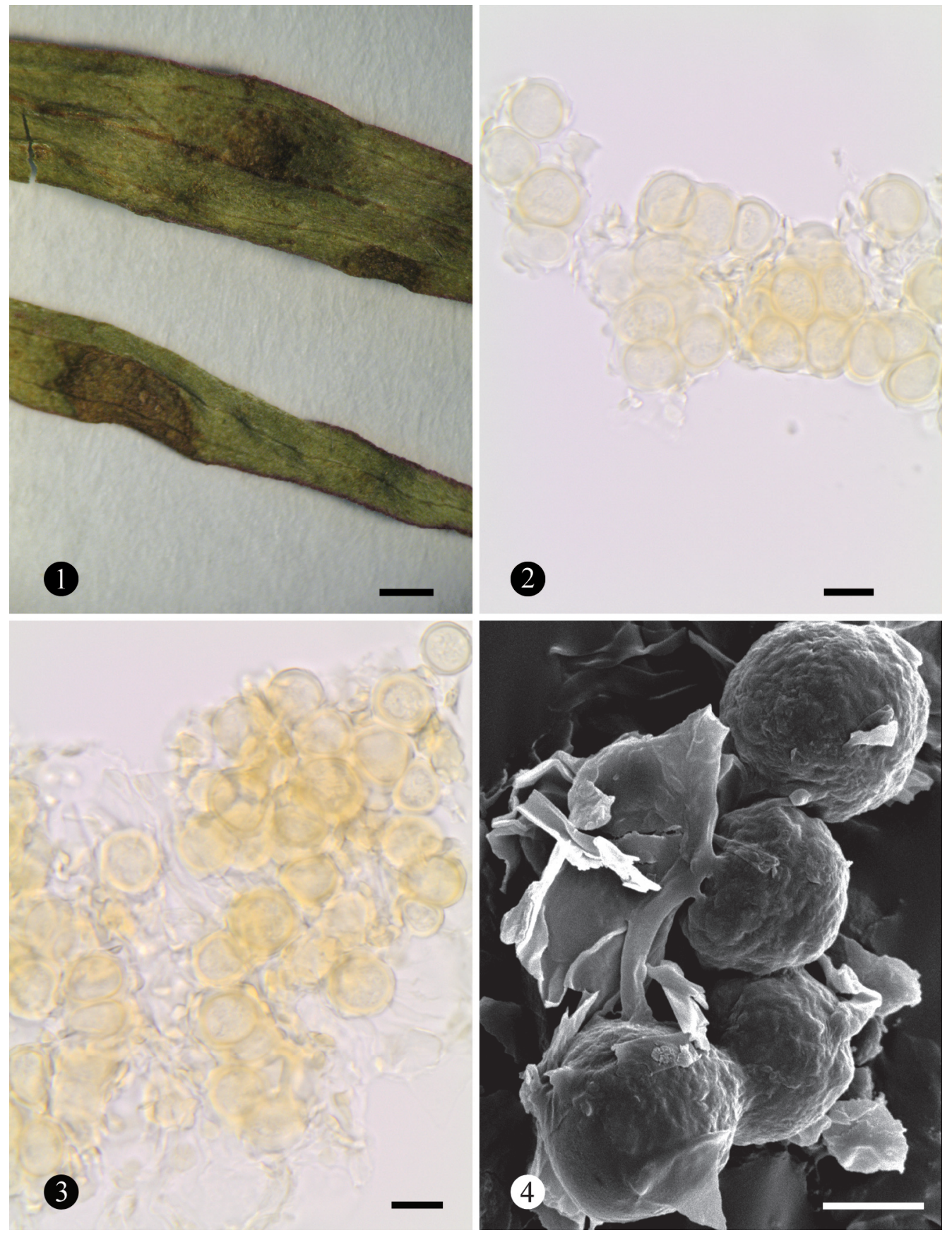

Figs 1-4. Entyloma castillejae on Castilleja (holotype). 1. Leaf spots. 2-3. Spores in LM. 4. Spores in SEM. Scale bars: $1=1 \mathrm{~mm}, 2-3=10 \mu \mathrm{m}, 4=5 \mu \mathrm{m}$ 
An Entyloma species on a member of Castilleja, C. miniata Douglas ex Hook., has been recorded only from Washington, USA (Shaw 1973) without assignment to a particular species.

In the traditional classifications, Castilleja was placed in the Scrophulariaceae (e.g., Cronquist 1981). However, numerous molecular systematic studies have demonstrated that Scrophulariaceae, as it is traditionally recognised, represents polyphyletic assemblage of taxa comprising more than seven distinct lineages of Lamiales (Tank et al. 2009). Currently, Castilleja is treated as belonging to the Orobanchaceae. There are no Entyloma species on plants in the Orobanchaceae.

Entyloma violae T. Denchev, Denchev \& R.G. Shivas, sp. nov.

Figs $5-8$

IF 550280

Differs from all other Entyloma species by specialisation on Viola.

Type in leaves of Viola sp.: USA, Colorado, Gothic Biol. Station, 1931, B. Palm (holotype, S F157 094).

Etymology: the name refers to the host species.

Sori in leaves, forming rounded spots, scattered, amphigenous, $0.5-3.5 \mathrm{~mm}$ in diam., initially yellowish green, later yellowish brown, paler on the margins, on the upper leaf surface becomes purplish with age (Fig. 5); not limited by veins, slightly protruding or flat. Spores embedded in leaf tissue, globose, subglobose or slightly irregular, (9.5-)10.0-15.5(-16.5) $\times(8.5-) 9.5-15.0[13.3 \pm 1.3 \times 12.3 \pm 1.2] \mu \mathrm{m}(\mathrm{n}=100)$, hyaline to subhyaline; wall twolayered, inner layer evenly thickened, $0.6-1.0 \mu \mathrm{m}$ thick, outer layer slightly uneven, $0.9-$ 2.0(-2.3) $\mu \mathrm{m}$ thick, smooth; in SEM the spore surface smooth. Anamorph present.

Distribution: on Viola (Violaceae), known only from the type locality.

\section{References}

Cronquist, A. 1981. An integrated system of classification of flowering plants. Columbia University Press, New York.

Farr, D.F. \& Rossman, A.Y. 2013. U.S. National Fungus Collections - Databases. ARS, USDA, Retrieved December 11, 2013, from http://nt.ars-grin.gov/fungaldatabases/.

Shaw, C.G. 1973. Host fungus index for the Pacific Northwest - I. Hosts. - Washington State University Agricultural Experiment Station, Bulletin 765: 1-121.

Tank, D.C., Egger, J.M. \& Olmstead, R.G. 2009. Phylogenetic classification of subtribe Castillejinae (Orobanchaceae). - Systematic Botany 34: 182-197.

Vánky, K. 2011 ['2012']. Smut fungi of the world. APS Press, St. Paul, Minnesota, USA.

Vánky, K. 2013. Illustrated genera of smut fungi. $3^{\text {rd }}$ edn. APS Press, St. Paul, Minnesota, USA. 

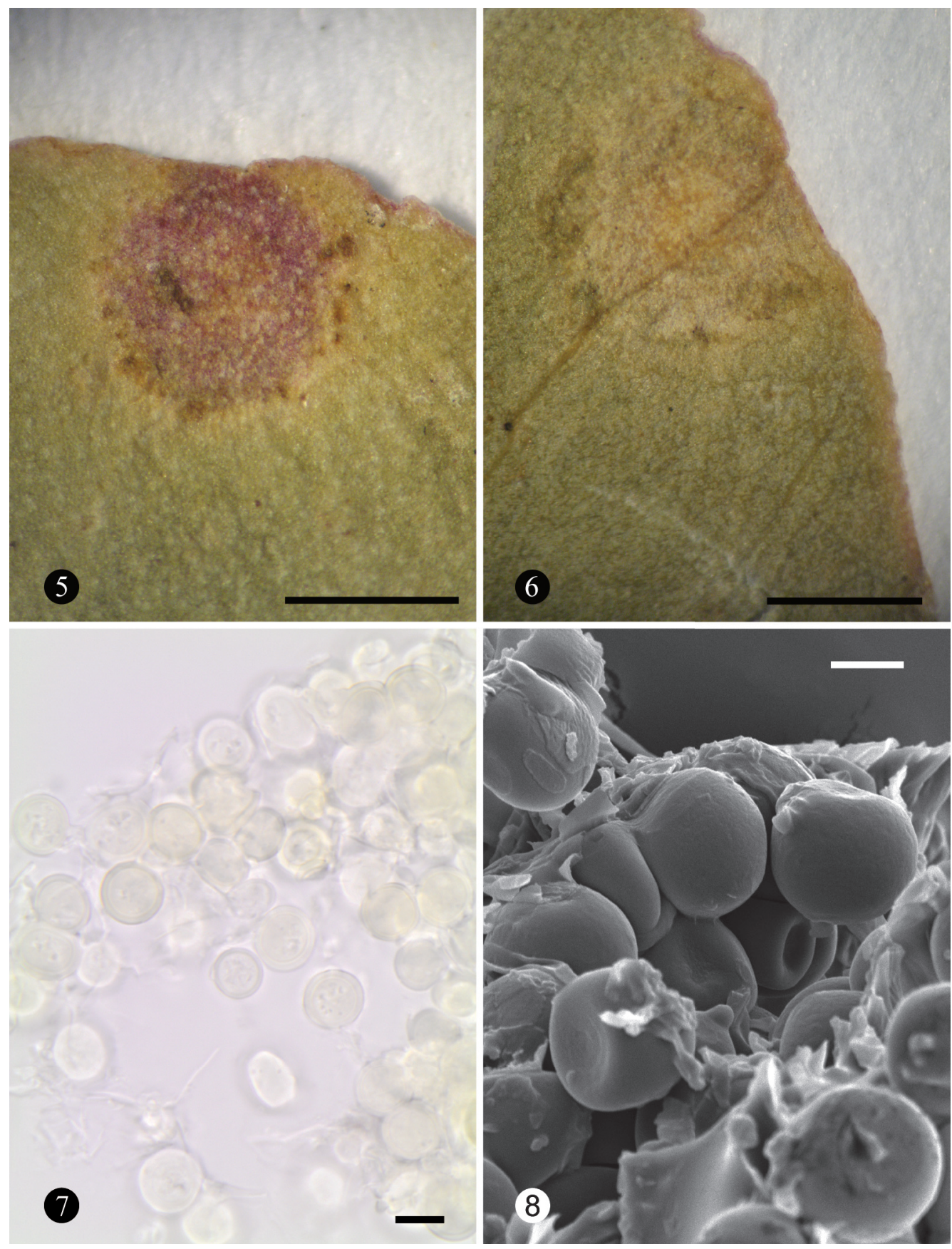

Figs 5-8. Entyloma violae on Viola (holotype). 5-6. Leaf spots (on the upper side and underside, respectively). 7. Spores in LM. 8. Spores in SEM. Scale bars: 5-6 $=1 \mathrm{~mm}, 7=10$ $\mu \mathrm{m}, 8=5 \mu \mathrm{m}$ 